\title{
Market efficiency and price discovery relationships between spot, futures and forward prices: the case of the Iberian Electricity Market (MIBEL)
}

\author{
Jose María Ballester, Francisco Climent \& Dolores Furió
}

To cite this article: Jose María Ballester, Francisco Climent \& Dolores Furió (2016) Market efficiency and price discovery relationships between spot, futures and forward prices: the case of the Iberian Electricity Market (MIBEL), Spanish Journal of Finance and Accounting / Revista Española de Financiación y Contabilidad, 45:2, 135-153, DOI: 10.1080/02102412.2016.1144441

To link to this article: http://dx.doi.org/10.1080/02102412.2016.1144441

Published online: 11 Mar 2016.

Submit your article to this journal $\llbracket$

Џ Article views: 23

View related articles $\sqsubset$

View Crossmark data $\nearrow$ 


\title{
Market efficiency and price discovery relationships between spot, futures and forward prices: the case of the Iberian Electricity Market (MIBEL)
}

\author{
Jose María Ballester, Francisco Climent and Dolores Furió \\ Financial Economics, University of Valencia, Valencia, Spain
}

\begin{abstract}
This paper analyses the relationships between prices from three different markets within the Spanish zone of the Iberian Electricity Market (MIBEL), namely futures, spot and over the counter (OTC) forward markets. The study focuses on three items: (i) contrasting the Weakform efficiency hypothesis of the markets involved in the study, (ii) analysing the Semi-strong-form efficient market hypothesis (EMH) of the MIBEL futures market and (iii) examining the price discovery relationships between the series of prices of the considered markets.

The empirical results confirm that 1-month-, 1-quarter-, 1-yearahead futures and spot markets satisfy, generally, the Weak-form efficiency hypothesis and that MIBEL futures market does not contradict the EMH in its Semi-strong-form. In addition, price discovery relationships have also been found. In particular, there is unidirectional causality from the futures market to the forward market and from the futures market to the spot market for 1-month- and 1quarter-ahead maturities. This result may be indicative of the agents to use the price of the futures market as a valuable reference.
\end{abstract}

\section{Eficiencia y price discovery entre los precios de contado, futuro y forwards: El caso del mercado Ibérico de la electricidad (MIBEL)}

\section{RESUMEN}

Este artículo analiza las relaciones entre los precios de los tres mercados existentes dentro de la zona española del Mercado Ibérico de la Electricidad, es decir, el mercado de futuros, contado y forward OTC. El estudio se centra en tres aspectos: (i) contrastar la hipótesis de eficiencia de mercado débil en los mercados involucrados en el estudio (ii) analizar la hipótesis de eficiencia de mercado semi-fuerte del mercado de futuros MIBEL y (iii) examinar el price discovery entre las series de precios de los mercados considerados.

Los resultados empíricos confirman que los mercados de futuros a 1-mes, 1-trimestre, 1-año vista y el mercado de contado cumplen, de forma general, la hipótesis de eficiencia de mercado débil y que el mercado de futuros MIBEL no contradice la hipótesis de eficiencia de mercado en su forma semi-fuerte. Adicionalmente, se han encontrado relaciones de price discovery entre los mercados analizados. En particular, se observa una relación de causalidad

\section{ARTICLE HISTORY}

Received 17 June 2014

Accepted 14 January 2016

\section{KEYWORDS}

Electricity prices; futures prices; efficiency

JEL CLASSIFICATION G14; C3; Q4 
unidireccional desde el mercado de futuros al mercado forward y desde el mercado de futuros al mercado de contado en los vencimientos a 1-mes y 1-trimestre vista. Estos resultados pueden ser indicativos del uso por parte de los agentes económicos del precio de futuro como precio de referencia.

\section{Introduction}

The deregulation process in European energy markets is a reality. The Spanish and Portuguese electricity markets make up the Iberian Electricity Market (MIBEL), setting up different markets where agents can go. There exist two distinct areas in MIBEL: the Spanish zone and the Portuguese zone. Usually, wholesale spot prices are the same and only differ due to congestion between the zones, which are managed by a market splitting mechanism. Thus, in the spot market, the generators and the retailers have a "pool" where they cross their supply and demand of electricity for the next day. There also exists an intraday market where agents can go to trade a few hours before the maturity date.

In addition, the system services market exists for adjusting the balance between production and consumption. Finally, agents can trade futures contracts through the derivatives exchange $\left(\mathrm{OMIP}^{1}\right)$ as well as over the counter (OTC) physically- or cashsettled bilateral forward contracts. Each futures contract involves the supply/reception of electricity at a constant power of $1 \mathrm{MW}$ during all hours of the delivery period (according to the maturity of each contract).

The OTC market allows for the negotiation of standardised and non-standardised contracts that exactly fit the interests of the parties involved in each operation. This paper selects those forward OTC contracts whose underlying asset is analogous to the ones of the futures contracts traded on the regulated futures market. The OTC market provides agents with an alternative to the regulated futures market to hedge the risk of price variation. In this sense, it should be noted that the Spanish OTC market existed prior to the futures market, with transaction records from the Reuters database existing since February 2003, whereas the futures market started in July $2006 .{ }^{2}$

One of the consequences of market liberalisation is the appearance of the price variation risk, which is notable in electricity markets. In fact, extreme values usually appear more often than in other commodities markets. ${ }^{3}$ This characteristic makes forward markets especially useful as a hedging tool.

In this context, it may be of relevance to test the efficiency of the above-mentioned markets as well as to know the true relationships between the different forward markets prices coexisting in the MIBEL so that participants can make optimal decisions. Regarding the latter, the Spanish National Energy Commission (CNE) explicitly encourages the monitoring of the Spanish OTC forward market prices and their relationships with the rest of forward markets such as the OMIP futures market (CNE (2010)). Furthermore, according to this official organism, the so-called CESUR auctions, which were held to set the price paid for power supplied on regulated tariffs in Spain until December 2013, may be explained by OTC forward prices. Therefore, the proposed analysis is justified from a regulatory and market supervision point of view, but it is also of interest for practitioners when designing their trading strategies on the different available markets. 
According to Fama (1970), an efficient market is a market in which prices always fully reflect available information. Besides, he makes a distinction between different types of efficient markets based on three definitions of the concept available information. Thus, the Weak-form of efficient markets assumes that historical price information is instantaneously impounded into prices. The Semi-strong-form of efficient markets assumes that publicly available information is also included into prices. Finally, the Strong-form of efficient markets implies that, apart from historical price and publicly available information, prices also reflect private information.

In the present work, we test the Weak-form and the Semi-strong-form efficient market hypothesis (EMH). The Strong-form EMH is definitely not easy to verify since it requires the use of non-public information.

Thus, first, we test the Weak-form efficiency hypothesis of each of the three markets involved in this study (i.e. spot, futures and forward OTC markets), individually considered. This hypothesis has been previously analysed in Higgs and Worthington (2003) for the Australian electricity spot market (period 1999-2001), with the result of that only one of the five regional market jurisdictions of the Australian National Electricity Market $\left(\mathrm{NEM}^{4}\right)$, the Victorian base-load spot market, fulfils the Weakform efficiency hypothesis.

Second, we test the Semi-strong EMH for the MIBEL futures market. This EMH form is normally tested in relation to the impact of the spot market on the futures market. On the one hand, under the cost-of-carry model, the no arbitrage condition, that involves taking position in both markets and storing the underlying asset until the expiration date of the futures contract, provides a link between the current futures price and the spot price. Thereby, the futures price should be an unbiased estimate of the future spot price. On the other hand, based on the principle that prices reflect all publicly available information, under the joint assumptions of risk neutrality and rationality, the expected returns to speculative activity in an efficient market should be zero.

In this particular setting, however, it is of note that the link between forward and spot prices based on the so-called cost-of-carry model may not be applicable, since electricity - in contrast to financial assets and most commodities - is not susceptible to be stored. Therefore, the above-referred no-arbitrage argument cannot hold. ${ }^{5}$ Consequently, in the context of electricity markets, the supposed link between forward and spot prices is not straightforward, mainly due to the non-storability of the underlying asset. Thus, once this link has been broken, it would make no sense to use spot prices as a valid information source to predict futures prices. To overcome that conceptual limitation, when addressing the issue of testing the Semi-strong-form EMH of the MIBEL futures market, instead of the series of spot prices, more-informational series of prices have been built, as a proxy for those series of spot prices that would be expected to be connected to futures prices. The proxies for the spot prices will be derived from the seasonal cost-of-carry model proposed by Borovkova and Geman (2006), which is precisely aimed at capturing the dynamics of electricity prices better than the classical cost-of-carry model, being that the latter is not valid for electricity markets, according to those authors. ${ }^{6}$

Last, the potential transmission information between the three Spanish electricity markets is also investigated. Thereby, the present work is additionally aimed to identify 
the role of each of these markets in the price discovery function. A number of studies can be found in the literature that also address this topic within the context of electricity markets. Among them, Feng, Liu, Lai, and Deng (2007), Yang, Liu, Zhang, and Luo (2009) and Redl, Haas, Huber, and Böhm (2009) focus on the Scandinavian market, whereas Redl et al. (2009) and Growitsch and Nepal (2009) centre on the German EEX market.

This paper is organised as follows: Section 2 describes the data used, including a descriptive analysis of them. Section 3 explains the methodology employed. Section 4 presents the empirical results and, finally, Section 5 concludes by summarising the major conclusions reached.

\section{Data}

MIBEL daily business spot, futures and OTC forward electricity prices are used, ${ }^{7}$ covering the period from 1 January 2007 to 31 December 2014. The spot reference price used for settlement at maturity is the SPEL index published by OMIP, which is obtained as the arithmetic average of the day-ahead market price for the 24 hours of the day. 1-month-ahead, 1-quarter-ahead and 1-year-ahead futures and forward OTC contracts are selected. Additionally, the 2-month-ahead, 3-month-ahead, 2-quarterahead and 3-quarter-ahead forward OTC prices have been used to build the proxy for spot prices.

The last trading day is different for each type of contract. So, for 1-month-ahead contracts, the last trading day corresponds to the trading day preceding the day before the eve of the first delivery day. For 1-quarter-ahead contracts, the last trading day corresponds to the second trading day preceding the day before the eve of the first delivery day and for 1-year-ahead contracts, the last trading day corresponds to the third trading day preceding the day before the eve of the first delivery day.

A first approximation of the behaviour of the data used can be seen in Table 1, which shows the main descriptive statistics. It can be observed that forward and futures prices are less volatile than spot prices. In addition, we can see that the average of the futures price increases with the delivery period, which is consistent with Botterud, Bhattacharyya, and Ilic (2002) and Longstaff and Wang (2004), while the volatility is reduced.

Table 1. Descriptive statistics of price series.

\begin{tabular}{lrcccccc}
\hline & SPOT & FUT_M+1 & FUT_Q+1 & FUT_Y+1 & FWD_M+1 & FWD_Q+1 & FWD_Y+1 \\
\hline Mean & 46.33 & 48.37 & 49.43 & 50.54 & 48.36 & 48.40 & 50.06 \\
Median & 46.80 & 48.33 & 49.00 & 50.00 & 48.33 & 48.74 & 49.95 \\
Maximum & 91.89 & 74.50 & 75.08 & 75.10 & 76.25 & 74.80 & 75.10 \\
Minimum & 0.00 & 24.25 & 29.13 & 38.33 & 24.00 & 19.90 & 33.05 \\
Std. Dev. & 13.46 & 9.80 & 8.48 & 6.27 & 9.71 & 9.73 & 7.44 \\
Skewness & -0.22 & 0.31 & 0.49 & 1.08 & 0.29 & 0.00 & 0.60 \\
Kurtosis & 3.93 & 3.00 & 3.34 & 5.30 & 3.05 & 3.38 & 4.32 \\
\hline
\end{tabular}

Sample Period: 01/01/2007-31/12/2014.

FUT_ $i$ : future contract price expiring $i$.

FWD_i: forward contract price expiring $i$.

SPOT: SPEL index price.

Where $i=M+1$ (month ahead), $Q+1$ (quarter ahead) and $Y+1$ (year ahead). 


\section{Methodology}

The econometric techniques are linked to the hypothesis to be examined. The Weak-form efficiency hypothesis (Fama, 1970) is analysed by means of the variance ratio test (VRT), whose aim is to contrast whether the series follow a random walk. In order to test the efficiency of the MIBEL futures market in its Semi-strong-form, cointegration techniques are used. Complementarily, a measure for market efficiency proposed by Kellard, Newbold, Rayner, and Ennew (1999) is also obtained. Last, with the aim of finding out whether there is information transmission between the series involved in the study, we also investigate their relationships through the vector error correction model (VECM).

\subsection{Weak-form efficient market hypothesis}

According to Fama (1970), the Weak-form efficiency can be tested by contrasting whether the price series follow a random walk. In this paper, in order to test such a hypothesis, we follow Lo and MacKinlay (1988) and use the VRT. ${ }^{8}$

Lo and Mackinlay's (1988) procedure is used to test the null hypothesis that an individual Variance Ratio for a specific interval $q$ equals 1, whereas the random walk hypothesis requires that $\operatorname{VR}(q)=1$ for all $q$. Chow and Denning's (1993) multiple variance ratio (MVR) test sets up a procedure for the multiple comparison of a set of variance ratios. ${ }^{9}$

Since the null hypothesis for a single VRT is $\operatorname{VR}(q)=1$, then $M_{r}(q)=\operatorname{VR}(q)-1=0$.

Consider a set of $m$ VRTs $\left\{M_{r}\left(q_{i}\right) \mid i=1,2, \ldots, m\right\}$. Under the null hypothesis of random walk, there are multiple sub-hypotheses:

$$
\begin{gathered}
\mathrm{H}_{0 i}: M_{r}\left(q_{i}\right)=0 \text { for } i=1,2, \ldots, m \\
\mathrm{H}_{1 i}: M_{r}\left(q_{i}\right) \neq 0 \text { for any } i=1,2, \ldots, m
\end{gathered}
$$

The rejection of any one or more $\mathrm{H}_{0 i}$ rejects the random walk hypothesis. Hence, the Chow and Denning's (1993) MVR test is based on the result of

$$
\operatorname{Prmax} Z q 1, \ldots, \leq S M M \alpha ; m ; \mathrm{N} \geq 1-\alpha
$$

where $\operatorname{SMM}(\alpha ; m ; N)$ is the $\alpha$ point of the standardised maximum modulus (SMM) distribution with parameters $m$ (number of variance ratios) and $N$ (sample size) degrees of freedom. Asymptotically, when $N$ approaches infinity, $\lim _{N \rightarrow \infty} \operatorname{SMM}(\alpha ; m ; N)=Z_{\alpha^{*} / 2}$,

where $\alpha^{*}=1-(1-\alpha)^{1 / m}$. If the maximum absolute value of $Z\left(q_{i}\right)$ is greater than the SMM critical value at a predetermined significance level, then the random walk hypothesis is rejected.

\subsection{Semi-strong-form efficient market hypothesis}

Following Hansen and Hodrick (1980), the EMH can be defined as follows:

Let $s(t)=\ln (\mathrm{S}(t))$ and $\mathrm{fwd}(t, T)=\ln (\mathrm{FWD}(t, T))$, where $\mathrm{S}(t)$ and $\mathrm{FWD}(t, T)$ are spot prices and forward prices with maturity $T$ determined at time $t$, respectively. The EMH is:

$$
\operatorname{Fwd}(t, T)=E\left(s(T) \mid \phi_{t}\right)
$$


where $E\left(\cdot / \phi_{t}\right)$ denotes the mathematical expectation conditioned on the information set available to agents at time $t$.

The EMH implies that the futures price is an unbiased estimator of the conditional expectation of the future spot price. Lai and Lai (1991) suggest the use of the Johansen (1988) statistical procedure, based on cointegration analysis, to apply the EMH to the futures market. We do this by testing whether futures prices and, instead of the spot price, the geometric average of the forward curve as a proxy for the spot price, are cointegrated. If so, it can be concluded that the futures market supports the EMH. Due to liquidity reasons, 1-month- and 1-quarter-ahead maturities have been selected.

The approach of using the geometric average of the forward curve as a proxy for spot prices was suggested by Borovkova and Geman (2006), given that the link between futures and spot prices, enshrined by the well-known cost-of-carry model, does not exist in this case. As stated by those authors, the absence of storability prevents any cash and carry argument, and in turn any spot-forward relationship between the spot price of electricity and forward prices. Consequently, they propose the seasonal cost-of-carry model for non-storable commodities:

$$
\begin{aligned}
F(t, T) & =\mathrm{GA}_{t} e^{[s(T)-\gamma(t, T-t) \cdot(T-t)]} \\
\mathrm{GA}_{t} & =\sqrt[N]{\prod_{T=1}^{N} \mathrm{Fwd}(t, T)}
\end{aligned}
$$

where $F(t, T)$ and $\operatorname{Fwd}(t, T)$ are the futures and forward price with maturity $T$ at time $t$, respectively, $N$ is the number of available maturities for a particular contract, $s(T)$ is a seasonal premium, which is deterministic and depends on the month of expiration, satisfying $\sum_{M=1}^{12} s(M)=0$, and $\gamma(t, T-t)$ is the stochastic 0premium, which should be modelled depending on the studied asset.

The model implies that spot price can be approximated by the deterministic part of the model, namely the geometric average of forward prices, $\mathrm{GA}_{t}$ (or alternatively, the arithmetic average of log-forward prices) adjusted by adding the seasonal component corresponding to the delivery period of the derivatives contract. In this study, due to liquidity reasons, up to 3-month-ahead monthly forward and up to 3-quarter-ahead quarterly forward contracts are used to calculate the proxy for the spot prices referred to the corresponding futures contracts. Then, we test whether each pair of (futures and proxyfor-the-spot) series is cointegrated using the Johansen (1988) statistical procedure. ${ }^{10}$

Previously to test for cointegration, the KPSS test (Kwiatkowski, Phillips, Schmidt, \& Shin, 1992) is chosen to assure that the series are non-stationary (as required). Under this test, the null hypothesis is stationarity while the alternative hypothesis is nonstationarity.

The KPSS statistic is based on the residuals of the OLS regression of $y_{t}$ on the exogenous variables $x_{t}$ :

$$
y_{t}=x_{t}^{\prime} \delta+\varepsilon_{t}
$$

The statistical Lagrange multiplier (LM) is defined as 
$\mathrm{LM}=\frac{\sum_{t} C(t)^{2}}{N^{2} f_{o}}$, where $f_{0}$ is an estimator of the residual spectrum at frequency zero, $C$ $(t)$ is a cumulative residual function: $C(t)=\sum_{\tau=1}^{t} \hat{\mathcal{\varepsilon}}_{\tau}$ based on the residuals of the previous regression and $N$ is the total number of observations. The null hypothesis to be tested is that the error term has zero variance regression.

Johansen and Juselius (1990) propose a procedure based on the principle of likelihood ratio under the assumption of normality, to test for cointegration. This procedure uses the VECM that does not distinguish, a priori, any order of causality between variables. ${ }^{11}$

$$
x_{t}=A_{1} x_{t-1}+\varepsilon_{t}
$$

The critical values are obtained by Johansen (1988), although Osterwald-Lenum (1992) recalculates these values through the Monte Carlo process, because Johansen (1988) tabulates critical values for a range of between two and five series, both inclusive. Thus, Osterwald-Lenum (1992) generalises extending the number of series to consider. These changed values will be used as critical values in this work.

\subsection{Market efficiency measure}

Kellard et al. (1999) proposed a measure of market efficiency that allows to quantify the degree of efficiency achieved by a particular market.

Starting from a quasi-ECM model (VECM where we take only one equation individually), the Kellard's market efficiency measure is useful to compare the level of efficiency between different markets.

The quasi-ECM model can be defined as follows:

$$
\begin{aligned}
s(t)-s(t-1)= & \theta_{0}+\theta_{1}(\mathrm{fwd}(t-\tau, T)-s(t-\tau)) \\
& +\sum_{i=1}^{k} \lambda_{i}(s(t-i)-s((t-\tau)-i)) \\
& +\sum_{i=1}^{k} \gamma_{i}\left(\mathrm{fwd}(t-i, T)-\mathrm{fwd}((t-\tau)-i, T)+\varepsilon_{t}\right.
\end{aligned}
$$

where $s(t)$ denotes the logarithm of spot price at time $t$, fwd $(t, T)$ denotes the price of forward with maturity $T$ at time $t, k$ is the number of lags of the yields of endogenous and exogenous variable, and $\theta_{1}$ measures the speed of endogenous variable adjustment towards equilibrium. The prediction error variance is the variance of $\varepsilon_{t}$, for which there exists an unbiased estimator of the fitted regression. On the other hand, the market efficiency of the forward market implies an estimate of fwd $(t-\tau, T)+E[s(t)-\mathrm{fwd}(t-\tau, T)]$, allowing for the possibility of a systematic risk premium in forward prices and the error variance of this predictor can be calculated by the variance of the series $(s(t)-\mathrm{fwd}(t-\tau, T))$. Thus, the ratio of error variance of these two estimations provides an alternative measure of the efficiency of futures prices as predictors of the expected value of spot prices. Thereby, the measure of market efficiency, $\phi_{c}$, has the following representation: 


$$
\phi_{c}=\frac{(N-2 k-2)^{-1} \sum_{t=1}^{T} \hat{\varepsilon}_{t}^{2}}{(N-1)^{-1} \sum_{t=1}^{N}[(s(t)-f w d(t-\tau, T))-(\overline{s(t)-f w d(t-\tau, T)})]^{2}}
$$

where $N$ is the number of observations, and $(2 k+2)$ the number of estimated parameters. Thus, the range of values that can take the efficiency measure is $0 \leq \phi_{c} \leq$ 1 , where $\phi_{c}=0$ represents a complete inefficiency.

$$
\begin{gathered}
M_{r}(q)=\operatorname{VR}(q)-1=0 \\
\left\{M_{r}\left(q_{i}\right) \mid i=1,2, \ldots, m\right\} \\
\mathrm{H}_{0 i}: M_{r}\left(q_{i}\right)=0 \text { for } i=1,2, \ldots, m \\
\mathrm{H}_{1 i}: M_{r}\left(q_{i}\right) \neq 0 \text { for any } i=1,2, \ldots, m \\
\lim _{N \rightarrow \infty} \operatorname{SMM}(\alpha ; m ; N)=Z_{\alpha^{*} / 2}
\end{gathered}
$$

\subsection{Price discovery relationships}

The VECM is a VAR model that is designed to be used with non-stationary series that have been proved to be cointegrated. The VECM restricts the long-term behaviour of the endogenous variables to converge to the cointegration relationship, while allowing for short-term dynamic adjustment. Moreover, Granger (1983) shows that if the series is cointegrated, the VECM model improves the VAR model in efficiency and forecasting.

Thus, the VECM representation illustrates the relationship between the concepts of cointegration and the Granger causality, being able to analyse the causality between the series, through the elements of the VECM. Thus, this paper uses an error correction model to test for the causality in the short and long term of $I(1)$ and cointegrated time series:

$$
\begin{aligned}
& \Delta Y_{t}=a_{1}+\sum_{i=1}^{p} Y_{i} \Delta Y_{t-i}+\sum_{j=1}^{p} \delta_{j} \Delta X_{t-j}+\beta_{1} \mu_{t-1}+\varepsilon_{t 1} \\
& \Delta X_{t}=a_{2}+\sum_{i=1}^{p} Y_{i}^{\prime} \Delta Y_{t-i}+\sum_{j=1}^{p} \delta_{j}^{\prime} \Delta X_{t-j}+\beta_{2} \mu_{t-1}+\varepsilon_{t 2}
\end{aligned}
$$

Where $Y_{t}$ and $X_{t}$ could be the spot, futures or forward logarithm price series, depending on the relationship to be analysed. $\beta_{1}$ and $\beta_{2}$ coefficients measure the speed of endogenous variable adjustment towards equilibrium. $\mu_{t-1}$ is the residual of cointegration regression delayed one period. If the error correction term is significant in both equations $\left(\beta_{1} \neq 0\right.$ and $\left.\beta_{2} \neq 0\right)$, there is long-term causality in both directions so that none of the variables can be considered weakly exogenous with respect to the parameters of the other equation, although, according to Engle, Hendry, and Richard (1983) the condition that there is no Granger causality is necessary but not sufficient for weak exogeneity. If the null hypothesis is accepted $\left(\delta_{j}=0\right.$ for $\left.j=1, \ldots, p\right)$, then we can say that $X$ does not cause $Y$ in the short term. If it is accepted that $\gamma_{i}^{\prime}=0$ for $i=1, \ldots, p$, then we can say that $Y$ does not cause $X$ in the short term. The joint hypothesis testing is done through the Wald test using $F$ statistics and/or $\chi^{2}$, and the number of lags is determined using the Akaike information criterion. 


\section{Empirical results}

The empirical analysis developed in this paper is structured as follows. First, the Weakform efficiency hypothesis is investigated by using the VRT in the series of spot, futures and OTC forward prices. Second, the efficiency of the MIBEL futures markets in its Semi-strong-form and the short-term causality between the proxy of the spot and the futures prices are analysed. To this end, the relationship between the price series of futures contracts and the geometric average of the forward curve properly modified by adding the seasonal component corresponding to the delivery period of the contract as a proxy for spot price - is studied, using cointegration analysis. Additionally, the market efficiency measure proposed by Kellard et al. (1999) is obtained. Finally, the relationships between the prices of these three markets are analysed by examining the causality between them and trying to determine the price discovery relationships.

\subsection{Testing the Weak-form efficiency hypothesis of the spot OTC forward and futures markets}

Following Fama (1970), the Weak-form efficiency hypothesis assumes that all information contained in historical prices are fully reflected in current prices. To verify this hypothesis, we test for the random walk hypothesis by means of the VRT.

The results of the Lo and MacKinlay (1988) individual VRT and Chow and Denning (1993) MVR are presented in Tables 2 and 3, respectively. The sampling intervals for the analysed series are 2, 5, 10 and 15 days.

Only for the 1-quarter-ahead futures contract in all analysed $q$ intervals, the null hypothesis is not rejected for random walk with heteroskedastic increments $\left(Z^{\star}(q)\right)$. For the rest of the examined series, at any given interval, the hypothesis of random walk is rejected. In order to analyse jointly the $m$ intervals, (in this case, 2, 5, 10 and 15) the MVR is used (Table 3).

Table 3 shows that the 1-quarter-ahead futures contract follows a random walk. Therefore, this market satisfies the Weak-form efficiency hypothesis. On the other hand, the null hypothesis that the natural logarithm of the 1-year-ahead futures price follows a random walk with homoskedastic increments is rejected, but fails to reject the random walk with heteroskedastic increments hypothesis. Therefore, the 1-year-ahead futures price follows a random walk and it is informationally efficient. For the rest of the analysed contracts and the spot price, the null hypothesis is rejected.

\subsection{Testing efficient Semi-strong-form market hypothesis of the MIBEL futures market}

According to our results, the series of futures prices for each of the considered maturities and the series of the proxy for spot prices are non-stationary (Table 4). ${ }^{12}$

The next step will be to check whether they are cointegrated. The method used to rollover futures (forward) price series is one that allows us at all times to deal with the nearby price, namely the price of the front contract or contract closest to expiration. Cointegration results are shown in Table 5. 
Table 2. Variance ratio test (VRT).

\begin{tabular}{lccccc}
\hline & & \multicolumn{4}{c}{ Sampling intervals $(q)$} \\
\cline { 2 - 5 } & Statistics & $q=2$ & $q=5$ & $q=10$ & $q=15$ \\
\hline \multirow{3}{*}{ FUT_M+1 } & $\operatorname{VR}(q)$ & 1.07096 & 1.135459 & 1.167999 & 1.190054 \\
& $Z(q)$ & $3.240947^{* * *}$ & $2.823865^{* * *}$ & $2.272536^{* * *}$ & $2.043439^{* * *}$ \\
& $Z^{*}(q)$ & $3.642058^{* * *}$ & $2.961578^{* * *}$ & $2.295972^{* *}$ & $2.008503^{* *}$ \\
FUT_Q+1 & $\operatorname{VR}(q)$ & 1.023393 & 1.026554 & 1.077523 & 1.088447 \\
& $Z(q)$ & 1.068438 & 0.553564 & 1.048658 & 0.950973 \\
& $Z^{*}(q)$ & 0.747501 & 0.468683 & 0.965189 & 0.898657 \\
FUT_Y+1 & $\operatorname{VR}(q)$ & 1.097673 & 1.202117 & 1.316675 & 1.364862 \\
& $Z(q)$ & $4.460994^{* * *}$ & $4.213458^{* * *}$ & $4.283692^{* * *}$ & $3.922966^{* * *}$ \\
& $Z^{*}(q)$ & $2.670829^{* * *}$ & $2.561061^{* *}$ & $2.664412^{* * *}$ & $2.486096^{* *}$ \\
FWD_M+1 & $\operatorname{VR}(q)$ & 0.90026 & 0.790218 & 0.75744 & 0.756054 \\
& $Z(q)$ & $-4.556503^{* * *}$ & $-4.374302^{* * *}$ & $-3.281923^{* * *}$ & $-2.623513^{* * *}$ \\
& $Z^{*}(q)$ & -1.541025 & $-1.913086^{*}$ & $-1.769507^{*}$ & -1.558226 \\
FWD_Q+1 & $\operatorname{VR}(q)$ & 0.880825 & 0.784466 & 0.765575 & 0.757301 \\
& $Z(q)$ & $-5.444364^{* * *}$ & $-4.494237^{* * *}$ & $-3.17185^{* * *}$ & $-2.6101^{* * *}$ \\
& $Z^{* *}(q)$ & $-3.747491^{* * *}$ & $-3.001232^{* * *}$ & $-2.322063^{* * *}$ & $-1.980831^{* *}$ \\
FWD_Y+1 & $\operatorname{VR}(q)$ & 0.83368 & 0.659427 & 0.656745 & 0.667352 \\
& $Z(q)$ & $-7.598105^{* * *}$ & $-7.101521^{* * *}$ & $-4.644364^{* * *}$ & $-3.577461^{* * *}$ \\
& $Z^{*}(q)$ & $-2.718096^{* * *}$ & $-3.059865^{* * *}$ & $-2.423057^{* *}$ & $-2.069213^{* *}$ \\
SPOT & $\operatorname{VR}(q)$ & 0.795659 & 0.427749 & 0.308314 & 0.232351 \\
& $Z(q)$ & $-9.335039^{* * *}$ & $-11.93239^{* * *}$ & $-9.358753^{* * *}$ & $-8.25567^{* * *}$ \\
& $Z^{* *}(q)$ & $-4.701646^{* * *}$ & $-6.18765^{* * *}$ & $-4.934043^{* * *}$ & $-4.479372^{* * *}$ \\
\hline
\end{tabular}

The VRT contrasts the null hypothesis of the series follows a random walk.

FUT_i: futures contract price expiring $i$.

FWD_i: forward contract price expiring $i$.

SPOT: SPEL index price.

Where $i=\mathrm{M}+1$ (month ahead), $\mathrm{Q}+1$ (quarter ahead) and $\mathrm{Y}+1$ (year ahead).

$\operatorname{VR}(q)$ is the variance ratio with interval $q$.

$Z(q)$ and $Z^{*}(q)$ are the test statistics for homoskedastic and heteroskedastic increments random walk.

Reject the null hypothesis at $1 \%(* * *), 5 \%(* *), 10 \%\left(^{*}\right)$ of significance level.

Table 3. Multiple variance ratio (MVR) test.

\begin{tabular}{lcll}
\hline & Statistics & Homoskedastic & Heteroskedastic \\
\hline FUT_M+1 & Max |Z| & $3.240947^{* * *}$ & $3.642058^{* * *}$ \\
FUT_Q+1 & at period & 2 & 2 \\
& Max |Z| & 1.068438 & 0.965189 \\
FUT_Y+1 & at period & 2 & 10 \\
& Max |Z| & $4.460994^{* * *}$ & $2.670829^{* *}$ \\
FWD_M+1 & at period & 2 & 2 \\
& Max |Z| & $4.556503^{* * *}$ & 1.913086 \\
FWD_Q+1 & at period & 2 & 5 \\
& Max |Z| & $5.444364^{* * *}$ & $3.747491^{* * *}$ \\
FWD_Y+1 & at period & 2 & 2 \\
& Max |Z| & $7.598105^{* * *}$ & $3.059865^{* * *}$ \\
SPOT & at period & 2 & 5 \\
& Max |Z| & $11.93239^{* * *}$ & $6.18765^{* * *}$ \\
\hline
\end{tabular}

The MVR test contrasts the null hypothesis of the series follows a random walk.

FUT_i: futures contract price expiring $i$.

FWD_i: forward contract price expiring $i$.

SPOT: SPEL index price.

Where $i=\mathrm{M}+1$ (month ahead), $\mathrm{Q}+1$ (quarter ahead) and $\mathrm{Y}+1$ (year ahead).

$\operatorname{Max}|\mathrm{Z}|$ is the maximum absolute value of the test statistic.

Reject the null hypothesis at $1 \%\left({ }^{* * *}\right), 5 \%(* *), 10 \%\left({ }^{*}\right)$ of significance level. 
Table 4. Stationarity test (KPSS).

\begin{tabular}{lccc}
\hline & KPSS & & First differences \\
\hline & Levels & & 0.033616 \\
\hline FUT_M+1 & 0.207673 & $* *$ & 0.043594 \\
FUT_Q+1 & 0.233346 & $* *$ & 0.027900 \\
FWD_M+1 & 0.209658 & $* *$ & 0.042264 \\
FWD_Q+1 & 0.206482 & $* *$ & 0.021387 \\
SPOT & 0.184949 & $* *$ & 0.059028 \\
GA & 0.223319 & & \\
\hline
\end{tabular}

The test contrasts the null hypothesis of stationarity against the alternative hypothesis of non-stationarity using the Lagrange multiplier test

Sample period: (01/01/2009-31/12/2014).

FUT_ $i$ : futures contract price expiring $i$.

FWD_i: forward contract price expiring $i$.

SPOT: SPEL index price.

LGA: geometric average of the forward curve plus the seasonal (monthly or quarterly) component.

Where $i=\mathrm{M}+1$ (month ahead) and $\mathrm{Q}+1$ (quarter ahead).

Reject the null hypothesis at $1 \%\left({ }^{* * *}\right), 5 \%\left({ }^{* *}\right), 10 \%\left(^{*}\right)$ of significance level.

Table 5. Cointegration test.

\begin{tabular}{|c|c|c|c|c|c|c|}
\hline & \multicolumn{3}{|c|}{$\lambda$ trace } & \multicolumn{3}{|c|}{$\lambda \max$} \\
\hline & $r=0$ & & $r \leq 1$ & $r=0$ & & $r=1$ \\
\hline GA - FUT_M+1 & 63.35825 & * & 5.091727 & 58.26653 & * & 5.091727 \\
\hline GA - FUT_Q+1 & 101.6021 & * & 0.234032 & 101.368 & * & 0.234032 \\
\hline
\end{tabular}

The Johansen cointegration test is performed by likelihood ratio of $\lambda$ trace $(\lambda$ max), being the null hypothesis that the number of cointegration vectors is less than or equal to $r$.

Sample period: 01/01/2009-31/12/2014

FUT_i: futures contract price expiring $i$.

GA: geometric average of the forward curve plus the seasonal (monthly or quarterly) component.

$i=\mathrm{M}+1$ (month ahead) and $\mathrm{Q}+1$ (quarter ahead).

${ }^{*}$ Reject the null hypothesis at $5 \%$ of significance level.

It can be observed that the series of 1-month-and 1-quarter-ahead futures prices and the corresponding series of the proxy for the spot prices are cointegrated. Therefore, we can conclude that the MIBEL futures market is efficient in its Semi-strong-form for the 1month-ahead and the 1-quarter-ahead futures contracts.

In addition, in order to quantify the degree of efficiency of futures markets, Kellard et al. (1999)'s market efficiency measure is computed. Spot prices are substituted by the corresponding above-referred proxy. The results are presented in Table 6. Kellard et al. (1999)'s market efficiency measure is higher for the 1-month-ahead futures contract than for the 1quarter-ahead contract, indicating a higher degree of efficiency associated with the former. However, these values are quite low when compared to other electricity markets such as Nord Pool (Yang et al., 2009). ${ }^{13}$ Also, in other commodity markets such as the soya bean $\left(\mathrm{CBOT}^{14}\right)$, live hogs and live cattle $\left(\mathrm{CME}^{15}\right)$ futures markets, Kellard et al. (1999) obtained values of 0.87, 0.99 and 0.77, respectively, for live hogs (1982-1996), live cattle (1982-1996) and soya beans (1979-1996). These results can be explained by the fact that the MIBEL

Table 6. Market efficiency measure.

\begin{tabular}{lr}
\hline FUT_M+1 & FUT_Q+1 \\
\hline 0.1259 & 0.0798 \\
\hline $0 \leq \phi_{c} \leq 1, \phi_{c}=0$ total inefficiency and $\phi_{c}=1$ total efficiency. \\
FUT_i: future contract price expiring $i$. \\
Where $i=M+1$ (month ahead), $Q+1$ (quarter ahead).
\end{tabular}


futures market is newly created and may lack the maturity of other more consolidated commodities futures markets.

\subsection{Price discovery relationships within MIBEL markets}

In this section, the transmission of information between prices of the three studied markets (spot, futures and OTC forward) is investigated. Thus, price discovery relationships are analysed between (i) futures and OTC forward prices, (ii) futures and spot prices and, finally, (iii) OTC forward and spot prices. These relationships are examined by using VECM models as they allow us to examine short- and long-term relationships between the involved price series.

Initially, a graphical view of each pair of series is displayed in Figures 1-3. As can be observed, futures and forward prices follow a similar pattern. Regarding the future-spot prices and the OTC forward-spot prices, the most noticeable difference can be found in the 1-quarter-ahead maturity, showing that the spot price is more volatile than the quarterly futures price, which is consistent with Samuelson hypothesis.
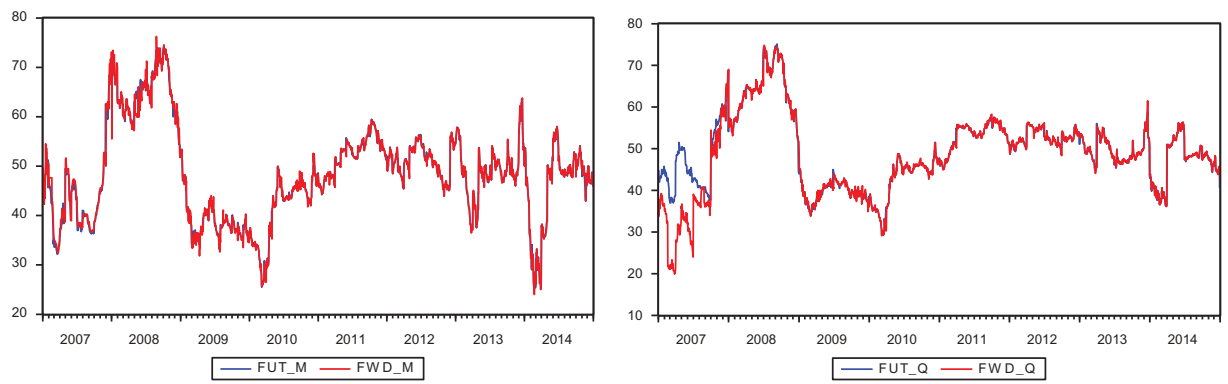

Figure 1. Futures and forward prices.

Price of 1-month- and 1-quarter-ahead of futures and forward contracts from 1 January 2007 to 31 December 2014.

FUT_i: futures contract price expiring $i$.

FWD_i: forward contract price expiring $i$.

Where $i=\mathrm{M}$ (month ahead), $\mathrm{Q}$ (quarter ahead).
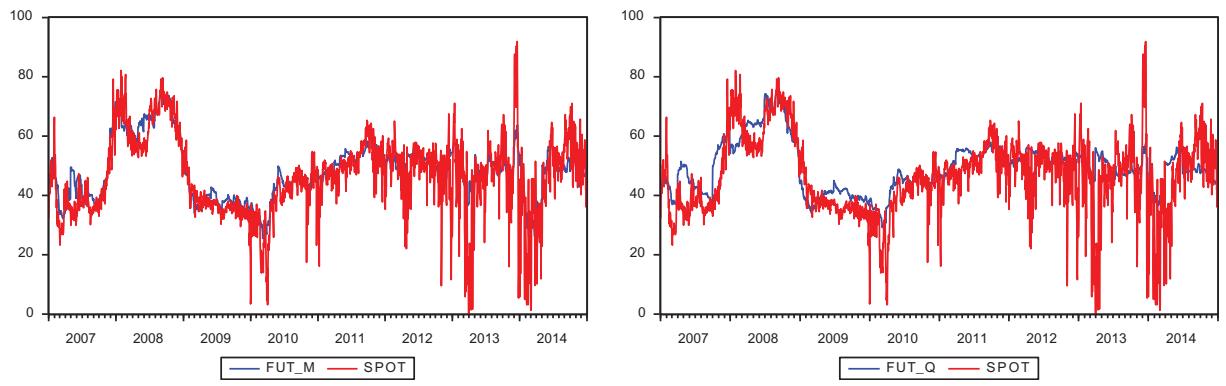

Figure 2. Futures and spot prices.

Price of 1-month- and 1-quarter-ahead of futures and spot contracts from 1 January 2007 to 31 December 2014.

FUT_ $i$ : futures contract price expiring $i$, where $i=M$ (month ahead), Q (quarter ahead).

SPOT: spot price (SPEL index price). 

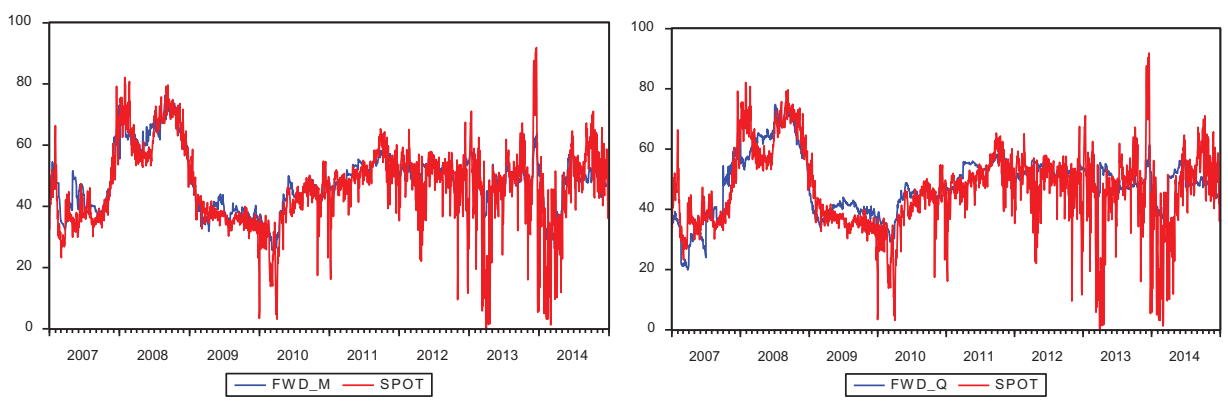

Figure 3. Forward and spot prices.

Price of 1-month- and 1-quarter-ahead of forward and spot contracts from 1 January 2007 to 31 December 2014.

FWD_i: futures contract price expiring $i$, where $i=M$ (month ahead), $Q$ (quarter ahead). SPOT: spot price (SPEL index price).

Table 7. Futures and forward prices relationships.

\begin{tabular}{|c|c|c|c|c|c|c|}
\hline Maturity (i) & $\begin{array}{c}\text { Endogenous } \\
\text { Variable }\end{array}$ & $\begin{array}{l}\text { Optimal } \\
\text { Lags }\end{array}$ & $\begin{array}{c}\text { FUT_i } i \\
\text { Long term }\end{array}$ & Short term & $\begin{array}{c}\text { FWD_i } \\
\text { Long term }\end{array}$ & Short term \\
\hline $\begin{array}{l}\text { Month } \\
\text { ahead }\end{array}$ & $\begin{array}{l}\text { FUT_i } \\
x^{2} \\
\text { FWD_i } \\
x^{2}\end{array}$ & 4 & $\begin{array}{c}\text { YES } \\
42.77649^{* * *}\end{array}$ & $\begin{array}{c}\text { YES } \\
220.3006^{* * *}\end{array}$ & $\begin{array}{c}\mathrm{NO} \\
1.022769\end{array}$ & $\begin{array}{c}\mathrm{NO} \\
4.248583\end{array}$ \\
\hline $\begin{array}{l}\text { Quarter } \\
\text { ahead }\end{array}$ & $\begin{array}{l}\hat{F U T} i \\
x^{2} \\
\text { FWD_i } \\
x^{2}\end{array}$ & 6 & $\begin{array}{c}\text { YES } \\
3.060735^{*}\end{array}$ & $\begin{array}{c}\text { YES } \\
61.96939^{* * *}\end{array}$ & $\begin{array}{c}\text { NO } \\
1.641726\end{array}$ & $\begin{array}{c}\text { NO } \\
8.114587\end{array}$ \\
\hline
\end{tabular}

Sample Period: 01/01/2007-31/12/2014

FUT_i: futures contract price expiring $i$, where $i=M+1$ (month ahead), $Q+1$ (quarter ahead).

FWD_i: forward contract price expiring $i$, where $i=M+1$ (month ahead), $Q+1$ (quarter ahead).

Reject the null hypothesis at $1 \%\left({ }^{* *}\right), 5 \%\left({ }^{* *}\right)$ or $10 \%\left({ }^{*}\right)$ of significance level.

Optimal lags have been determined by Akaike information criterion.

Table 8. Futures and spot prices relationships.

\begin{tabular}{|c|c|c|c|c|c|c|}
\hline Maturity (i) & $\begin{array}{l}\text { Endogenous } \\
\text { Variable }\end{array}$ & $\begin{array}{l}\text { Optimal } \\
\text { Lags }\end{array}$ & $\begin{array}{c}\text { SPOT } \\
\text { Long term }\end{array}$ & Short term & $\begin{array}{c}\text { FUT_i } \\
\text { Long term }\end{array}$ & Short term \\
\hline $\begin{array}{l}\text { Month } \\
\text { ahead }\end{array}$ & $\begin{array}{l}\text { SPOT } \\
x^{2} \\
\text { FUT_i } i \\
x^{2}\end{array}$ & 2 & $\begin{array}{c}\text { YES } \\
9.159555^{* * *}\end{array}$ & $\begin{array}{c}\text { YES } \\
10.7811^{* * *}\end{array}$ & $\begin{array}{c}\text { YES } \\
227.1212^{* * *}\end{array}$ & $\begin{array}{c}\text { YES } \\
134.6505^{* * *}\end{array}$ \\
\hline $\begin{array}{l}\text { Quarter } \\
\text { ahead }\end{array}$ & $\begin{array}{l}\lambda \\
\text { SPOT } \\
x^{2} \\
\text { FUT_i } i \\
x^{2}\end{array}$ & 4 & $\begin{array}{c}\text { NO } \\
0.000139\end{array}$ & $\begin{array}{c}\text { No } \\
2.570421\end{array}$ & $\begin{array}{c}\text { YES } \\
81.7656^{* * *}\end{array}$ & $\begin{array}{c}\text { YES } \\
101.0151^{* * *}\end{array}$ \\
\hline
\end{tabular}

Sample Period: 01/01/2007-31/12/2014

FUT_ $i$ : futures contract price expiring $i$, where $i=M+1$ (month ahead), $Q+1$ (quarter ahead).

SPOT: spot price (SPEL index price).

Reject the null hypothesis at $1 \%\left({ }^{* *}\right), 5 \%(* *)$ or $10 \%(*)$ of significance level.

Optimal lags have been determined by Akaike information criterion.

In Tables 7-9 the price discovery relationships between all pairs of prices are summarised. Looking at the results in Table 7, we find that regarding the monthahead and the quarter-ahead contracts, in the short and the long run, futures prices help to predict forward prices but not vice versa. 
Table 9. Forward and spot prices relationships.

\begin{tabular}{|c|c|c|c|c|c|c|}
\hline Maturity (i) & $\begin{array}{c}\text { Endogenous } \\
\text { Variable }\end{array}$ & $\begin{array}{l}\text { Optimal } \\
\text { Lags }\end{array}$ & $\begin{array}{c}\text { SPOT } \\
\text { Long term }\end{array}$ & Short term & $\begin{array}{l}\text { FWD_i } \\
\text { Long term }\end{array}$ & Short term \\
\hline $\begin{array}{l}\text { Month } \\
\text { ahead }\end{array}$ & $\begin{array}{l}\text { SPOT } \\
X^{2} \\
\text { FWD_i } \\
X^{2}\end{array}$ & 2 & $\begin{array}{c}\text { YES } \\
209.7023^{* * *}\end{array}$ & $\begin{array}{c}\text { YES } \\
35.69678^{* * * *}\end{array}$ & $\begin{array}{c}\text { YES } \\
13.48194^{* * *}\end{array}$ & $\begin{array}{c}\mathrm{NO} \\
2.49058\end{array}$ \\
\hline $\begin{array}{l}\text { Quarter } \\
\text { ahead }\end{array}$ & $\begin{array}{l}\text { SPOT } \\
X^{2} \\
\text { FWD_i } \\
X^{2}\end{array}$ & 4 & $\begin{array}{c}\text { NO } \\
0.789392\end{array}$ & $\begin{array}{c}\text { NO } \\
1.582339\end{array}$ & $\begin{array}{c}\text { YES } \\
84.51706^{* * *}\end{array}$ & $\begin{array}{c}\text { YES } \\
39.24559^{* * *}\end{array}$ \\
\hline
\end{tabular}

Sample Period: 01/01/2007-31/12/2014

FWD_i: forward contract price expiring $i$, where $i=\mathrm{M}+1$ (month ahead), $\mathrm{Q}+1$ (quarter ahead). SPOT: spot price (SPEL index price).

Reject the null hypothesis at $1 \%\left({ }^{* *}\right), 5 \%\left(^{* *}\right)$ or $10 \%\left(^{*}\right)$ of significance level.

Optimal lags have been determined by Akaike information criterion.

Due to the fact that futures and forward contracts with the same maturity share the same underlying asset, one would have expected a bidirectional effect, at least in the long run. However, this intuition is not necessarily true in the short run, and according to our results, futures prices cause forward prices but generally not in the other way. This result may be indicative of the agents to be confident on the price of the futures market and use it as a reference when they bid into the OTC forward market.

Regarding the relationship between futures and spot prices, Table 8 shows that there is bidirectional causality in both, the long and the short run between 1-month-ahead futures and spot prices. For the 1-quarter ahead maturity, there is unidirectional causality from the futures prices to the spot prices.

Finally, Table 9 summarises the causal relationships between OTC forward and spot prices. Thus, for 1-month-ahead contracts, there exists bidirectional causality between the OTC forward 1-month-ahead and spot prices in the long term; on the other hand, with respect to 1-quarter-ahead contracts, there exists unidirectional causality from OTC forward prices to spot in the short and the long term.

To recapitulate, generally, there is bidirectional causality from futures and OTC forward prices to spot prices meaning that there is not a price discovery relationship between them. In other words, the futures and OTC forward markets lead the spot market and vice versa. Bidirectionality between futures and forward prices is not observed, but in general, the former drives the latter.

The results derived from the previous works are mixed. Thus, Yang et al. (2009) and Feng et al. (2007) find that futures and OTC forward markets play a leading role in the price discovery function with regards to the spot market for the Scandinavian market. Also, Growitsch and Nepal (2009) conclude that all maturities in futures and OTC forward prices lead spot prices in the German market, which indicates, according to those authors, that the futures and the OTC forward markets are efficient and liquid. Bidirectional causality between futures and forward prices is also found. Contrarily, Redl et al. (2009) analyse the German and the Scandinavian market and find that it is spot prices that cause, in the Granger sense, futures prices, in both markets. 


\section{Conclusions}

This paper focuses on analysing the efficiency as well as the relationships between futures and OTC forward prices with maturities of 1-month- and 1-quarter-ahead, and spot prices for electricity related to the Spanish zone, over the period 2007-2014. From this analysis, the following main results are emphasised: (i) 1-month-, 1-quarter, 1-year-ahead futures and spot markets verify the Weak-form efficiency hypothesis, (ii) the MIBEL futures market does not contradict the EMH in its Semi-strong-form and (iii) price discovery relationships have also been found. In particular, futures prices have an impact on forward prices for monthly and quarterly maturities, which may be indicative of a reliable price formation process in the futures market. Furthermore, empirical evidence of unidirectional Granger causality from 1-month-ahead and 1-quarter-ahead futures prices to spot prices is also obtained, indicating that the futures market plays a leading role in the price discovery function. Finally, there is evidence of unidirectional Granger causality from 1-quarterahead OTC forward prices to spot prices.

This leading role of the futures market over the OTC forward market may seem striking, given that the trading volume of the former is considerably lower than that of the latter. However, it is also a remarkable the fact that futures markets are characterised by information transparency in terms of prices, trading volumes, open interest, etc. as opposite to the OTC forward markets, where there exists no obligation to make prices or trading volumes publicly available. Furthermore, there is not a unique information source of OTC prices for the Spanish electricity market. Prices are typically disclosed by information providers agencies, which obtain their information from regular surveys made to their information providers (usually market participants) and, most importantly, the displayed data does not need to be referred to actual trades, but they can be just non-firm bids. The price transparency of the futures market, which is so relevant for market traders, as opposite to the opacity of the OTC forward market, may make them to consider futures prices as a good reference for quoting their own ask/bid prices on the OTC market, obviously not the only one but among the reliable sources of information.

These conclusions provide relevant information about the relationships of three important markets coexisting in MIBEL, responding to the need, pointed out by the Spanish $\mathrm{CNE}$, of studying the relationships of the different markets within MIBEL. Moreover, these results are also of relevance to practitioners when designing their trading strategies.

\section{Notes}

1. Iberian forward market operator.

2. The volume traded in 2013 in the futures market was $40,880 \mathrm{GWh}$, while the OTC market volume reached 328.500 GWh (CNMC, 2014).

3. For more details about the characteristics of electricity prices, see Bessembinder and Lemmon (2002).

4. The remainder regional market areas are Queensland, New South Wales, South Australia and Tasmania. Western Australia and Northern Territory are other zonal markets that are not interconnected to the NEM.

5. In order to use the cost-of-carry relationship to link Nord Pool spot and futures price, Deng (2005) argues for the possibility of storing electrical energy indirectly, through the water stored in reservoirs, to generate electricity.

6. Some other articles, however, have tested the efficiency of electricity markets by analysing the relationships between spot and forward prices without taking into account these 
considerations. Focused on the Nord Pool market, Yang et al. (2009) analyse the relationships between spot and weekly futures prices for the period 1996-2003, and conclude that the Nord Pool futures market satisfies the $\mathrm{EMH}$, and that the futures market plays a dominant role in the price discovery function. Feng et al. (2007) analyse the long-term equilibrium relationships between spot and futures markets with annual maturity covering the period from January 2006 to June 2006. They obtain unidirectional Granger causality from the futures market to the spot market, being more noticeable in the long term. These authors also conclude that the Nord Pool futures market confirms the EMH. According to our view, the purpose of these analyses cannot be to test market efficiency. Being that there are no theoretical arguments whereby both series of prices should be related, their results may not have implications for a higher or lower degree of market efficiency.

7. The spot and futures prices are extracted from the OMIP database, while forward prices are obtained from the Reuters database. All the prices (spot, futures and OTC prices) are related to the Spanish zone.

8. Some previous works have used the unit root test instead. However, the unit root test has been criticised for its low power (Smith, Jefferis, \& Ryoo, 2002) and because it cannot be used to test the Weak-form efficiency hypothesis since it is not focused on the predictability of prices (Campbell, Lo, \& MacKinlay, Adamek, \& Viceira, 1997).

9. For a detailed description of the VRT, see Appendix 1.

10. The cointegration equilibrium relationship is understood as an equilibrium relationship in the long term between forward and spot prices with the same underlying asset. Although both series of prices can fluctuate individually out of equilibrium for some time, there are forces that act to restore that balance.

11. For more details, see Appendix 2.

12. Table 4 also shows the KPSS for all analysed series.

13. 0.47 for the period 2000-2003.

14. Chicago Board of Trade.

15. Chicago Mercantile Exchange.

\section{Acknowledgements}

We thank an anonymous referee for his/her valuable comments and suggestions.

\section{Disclosure statement}

No potential conflict of interest was reported by the authors.

\section{Funding}

The authors wish to express their gratitude to the Spanish Ministry of Education and Science for their financial support. Financial support from CICYT project ECO2013-40186-P, University of Valencia project UV-INV-PRECOMP13-115547 and Cátedra de Finanzas Internacionales Banco Santander is gratefully acknowledged.

\section{References}

Bessembinder, H., \& Lemmon, M. L. (2002). Equilibrium pricing and optimal hedging in electricity forward markets. The Journal of Finance, 57, 1347-1382. doi:10.1111/15406261.00463

Borovkova, S., \& Geman, H. (2006). Seasonal and stochastic effects in commodity forward curves. Review of Derivatives Research, 9, 167-186. doi:10.1007/s11147-007-9008-4 
Botterud, A., Bhattacharyya, A. K., \& Ilic, M. (2002). Futures and spot prices - an analysis of the Scandinavian electricity market. In Proceedings of the 34th Annual North American Power Symposium. Tempe, AZ: Arizona State University.

Campbell, J. Y., Lo, A. W., MacKinlay, C. A., Adamek, P., \& Viceira, L. M. (1997). The Econometrics of Financial Markets. Princeton, NJ: Princeton University Press.

Chow, K. V., \& Denning, K. (1993). A simple multiple variance ratio test. Journal of Econometrics, 58, 385-401. doi:10.1016/0304-4076(93)90051-6

CNE. 2010. Informe sobre la relación de los precios de mercado spot y el de los mercados a plazo, 27 de Julio de 2010. Madrid: Comisión Nacional de Energia.

CNMC. 2014. Spanish energy regulators's national report to the European Commission 2014, 31st July. Madrid: Comisión Nacional de los Mercados y la Competencia.

Deng, D., 2005. Three essays on electricity spot and financial derivative prices at the Nordic power exchange. Unpublished doctoral dissertation. Göteborg University, Sweden.

Engle, R. F., Hendry, D. F., \& Richard, J.-F. (1983). Exogeneity. Econometrica, 51, 277-304. doi: $10.2307 / 1911990$

Fama, E. (1970). Efficient capital markets: A review of theory and empirical work. The Journal of Finance, 25, 383-417. doi:10.2307/2325486

Feng, W., Liu, S., Lai, M., \& Deng, X. 2007. Empirical research on price discovery efficiency in electricity futures market. In Paper presented at the power engineering society general meeting. Tampa, FL: IEEE.

Granger, C. W. J. (1983). Cointegrated variables and error correction models. Discussion paper, 83-13a. San Diego, CA: University of California.

Growitsch, C., \& Nepal, R. (2009). Efficiency of the German electricity wholesale market. European Transactions on Electrical Power, 19, 553-568. doi:10.1002/etep.v19:4

Hansen, L. A., \& Hodrick, R. J. (1980). Forward exchange rates as optimal predictors of future spot rates: An econometric analysis. Journal of Political Economy, 88, 829-853. doi:10.1086/ 260910

Higgs, H., \& Worthington, A. (2003). Evaluating the informational efficiency of Australian electricity spot markets: Multiple variance ratio tests of random walks. Pacific and Asian Journal of Energy, 13, 1-16.

Johansen, S. (1988). Statistical analysis of cointegration vectors. Journal of Economic Dynamics and Control, 12, 231-254. doi:10.1016/0165-1889(88)90041-3

Johansen, S., \& Juselius, K. (1990). Maximum likelihood estimation and inference on cointegration - with applications to the demand for money. Oxford Bulletin of Economics and Statistics, 52, 169-210. doi:10.1111/j.1468-0084.1990.mp52002003.x

Kellard, N., Newbold, P., Rayner, T., \& Ennew, C. (1999). The relative efficiency of commodity futures markets. The Journal of Futures Markets, 19, 413-432. doi:10.1002/(ISSN)1096-9934

Kwiatkowski, D., Phillips, P. C. B., Schmidt, P., \& Shin, Y. (1992). Testing the null hypothesis of stationarity against the alternative of a unit root. Journal of Econometrics, 54, 159-178. doi:10.1016/0304-4076(92)90104-Y

Lai, K. S., \& Lai, M. (1991). A cointegration test for market efficiency. The Journal of Futures Markets, 11, 567-575. doi:10.1002/(ISSN)1096-9934

Lo, A., \& MacKinlay, A. C. (1988). Stock market prices do not follow random walks: Evidence from a simple specification test. Review of Financial Studies, 11, 41-66. doi:10.1093/rfs/1.1.41

Longstaff, F. A., \& Wang, A. W. (2004). Electricity forward prices: A high-frequency empirical analysis. The Journal of Finance, 59, 1877-1900. doi:10.1111/jofi.2004.59.issue-4

Osterwald-Lenum, M. A. (1992). A note with quantiles of the asymptotic distribution of the maximum likelihood cointegration rank test statistics. Oxford Bulletin of Economics and Statistics, 54, 461-472. doi:10.1111/obes.1992.54.issue-3

Redl, C., Haas, R., Huber, C., \& Böhm, B. (2009). Price formation in electricity forward markets and the relevance of systematic forecast errors. Energy Economics, 31, 356-364. doi:10.1016/j. eneco.2008.12.001

Smith, G., Jefferis, K., \& Ryoo, H.-J. (2002). African stock markets: Multiple variance ratio tests of random walks. Applied Financial Economics, 12, 475-484. doi:10.1080/09603100010009957 
Yang, H., Liu, S., Zhang, Y., \& Luo, X. (2009). Empirical research on efficiency of the electricity futures market. International Journal of Emerging Electricity Power Systems, 10, 1-6.

\section{Appendix 1}

\section{Variance Ratio Test - Lo and MacKinlay (1988)}

Consider a random walk with drift:

$$
p_{t}=p_{t-1}+\beta+\varepsilon_{t}
$$

where $p_{t}$ is the natural logarithm of electricity spot or forward price, $\beta$ is a drift parameter and $\varepsilon_{t}$ is the residuals of the regression satisfying $E\left(\varepsilon_{t}\right)=0$ and $E\left(\varepsilon_{t} \varepsilon_{t-g}\right)=0, \mathrm{~g} \neq 0$, for all $t$.

The VRT proposed by Lo and MacKinlay (1988) is based on the assumption that the variance of random walk increments must be a linear function of the time interval. If a time series follows a random walk process, the variance of a $q$ th differenced variable is $q$ times as large as the firstdifferenced variable. For a time series partitioned into equality spaced intervals:

$$
\operatorname{Var}\left(p_{t}-p_{t-q}\right)=q \operatorname{Var}\left(p_{t}-p_{t-1}\right)
$$

where $q$ is any positive integer. The variance ratio is denoted by

$$
\operatorname{VR}(q)=\frac{\frac{1}{q} \operatorname{Var}\left(p_{t}-p_{t-q}\right)}{\operatorname{Var}\left(p_{t}-p_{t-1}\right)}=\frac{\sigma^{2}(q)}{\sigma^{2}(1)}
$$

such that under the null hypothesis $\operatorname{VR}(q)=1$. For a sample of $n q+1$ observations $\left(p_{0}, p_{1}, \ldots\right.$, $\left.p_{n q}\right)$, Lo and MacKinlay (1988) unbiased estimates of $\sigma^{2}(1)$ and $\sigma^{2}(q)$ are as follows:

$$
\hat{\sigma}^{2}(1)=\frac{\sum_{k=1}^{n q}\left(p_{k}-p_{k-1}-\hat{\mu}\right)^{2}}{(n q-1)}
$$

And

$$
\hat{\sigma}^{2}(q)=\frac{\sum_{k=q}^{n q}\left(p_{k}-p_{k-q}-q \hat{\mu}\right)^{2}}{h}
$$

where $\hat{\mu}$ is the sample mean of $\left(p_{t}-p_{t-1}\right)$ and

$$
h=q(n q+1-q)\left(1-\frac{q}{n q}\right)
$$

Lo and MacKinlay (1988) develop two test statistics, $Z(q)\left(Z^{*}(q)\right)$ under the null hypothesis of homoskedastic (heteroskedastic) increments random walk. If the null hypothesis is true, the associated test statistic has an asymptotic standard normal distribution.

For homoskedastic increments, random walk $Z(q)$ is

$$
Z(q)=\frac{\widehat{V R}(q)-1}{\hat{\sigma}_{0}(q)}
$$

where

$$
\hat{\sigma}_{0}=\left[\frac{2(2 q-1)(q-1)}{3 q(n q)}\right]^{1 / 2}
$$

And for heteroskedastic increments, random walk $Z^{\star}(q)$ is 


$$
Z^{*}(q)=\frac{\widehat{V R}(q)-1}{\hat{\sigma}_{e}(q)}
$$

where

$$
\hat{\sigma}_{e}(q)=\left[4 \sum_{k=1}^{q-1}\left(1-\frac{k}{q}\right)^{2} \hat{\delta}_{k}\right]^{1 / 2}
$$

And

$$
\hat{\delta}_{k}=\frac{\sum_{j=(k+1)}^{n q}\left(p_{j}-p_{j-1}-\hat{\mu}\right)^{2}\left(p_{j-k}-p_{j-k-1}-\hat{\mu}\right)^{2}}{\left[\sum_{j=1}^{n q}\left(p_{j}-p_{j-1}-\hat{\mu}\right)^{2}\right]^{2}}
$$

\section{Appendix 2 \\ Cointegration Test - Johansen and Juselius (1990)}

The starting point is the methodology of vector autoregressive (VAR) from the following expression:

$$
x_{t}=A_{1} x_{t-1}+\varepsilon_{t}
$$

where $X_{t}$ and $\varepsilon_{t}$ are vectors $n \times 1 ; A_{1}$ is the parameters matrix $(n \times n)$. Subtracting $X_{t-1}$ in both parts of the equation, it is obtained

$$
\begin{gathered}
\Delta x_{t}=A_{1} x_{t-1}-x_{t-1}+\varepsilon_{t} \\
=\left(A_{1}-I\right) x_{t-1}+\varepsilon_{t} \\
=\pi x_{t-1}+\varepsilon_{t}
\end{gathered}
$$

where $I$ is the identity matrix $(n \times n)$ and $\pi$ is $\left(A_{1}-I\right)$. The range of $\pi$ indicates the number of independent cointegration vectors, which can be obtained by checking the significance of the characteristic root (eigenvalues) of $\pi\left(\lambda_{i}\right)$ that establishes the matrix rank. There are several ways to generalise the model, for example, the inclusion of a drift in the equation, the inclusion of a constant in the cointegrating vector or both at once.

If the time series that makes up $x_{t}$ are not cointegrated, the range of $\pi$ is zero and all its characteristic roots are equal to 1 . The Johansen cointegration test for determining the number of characteristic roots that are different from the unit can be determined using the following two statistics:

The trace statistic tests the null hypothesis that the number of cointegrating vectors is less than or equal to $r$ against the alternative hypothesis that it is not the case:

$$
\lambda_{\text {trace }}(r)=-N \sum_{i=r+1}^{n} \ln \left(1-\hat{\lambda}_{i}\right)
$$

where $\hat{\lambda}_{i}$ are the estimate values of the characteristic roots obtained by estimating $\pi$ and $N$ is the total number of observations.

The second statistic ( $\lambda$ maximum) tests the null hypothesis that the number of cointegrating vectors is $r$ against the alternative that it is $r+1$ :

$$
\lambda_{\max }(r, r+1)=-N \ln \left(1-\hat{\lambda}_{r+1}\right)
$$

